\title{
Large variations in antioxidant capacity and contents of Hungarian sour and sweet cherry cultivars
}

\author{
Papp, N. ${ }^{1,2}$, Nyéki, J. ${ }^{1}$, Szabó, Z. ${ }^{1}$, Stefanovits-Bányai, E. ${ }^{2}$, Szabó, T. ${ }^{3}$ \& Hegedús, A. ${ }^{4}$ \\ ${ }^{1}$ University of Debrecen, Institute for Extension and Development, H- 4032 Debrecen, Böszörményi út 138, Hungary \\ ${ }^{2}$ Corvinus University of Budapest, Department of Applied Chemistry, H-1118 Budapest, Villányi út 29-31, Hungary \\ ${ }^{3}$ Research and Extension Centre for Fruit Growing, Úffehértó, H-4244 Úfehértó, Vadastag út 2, Hungary \\ ${ }^{4}$ Corvinus University of Budapest, Department of Genetics and Plant Breeding, H-1118 Budapest, Ménesi út 44, \\ Hungary; e-mail: hegedus.attila@uni-corvinus.hu
}

\begin{abstract}
Summary: Sour cherry (Prunus cerasus L.) cultivars grown in Hungary are of local origin while most sweet cherry cultivars in Hungary are introduced from other countries. A great phenotypic variability is displayed by both species. In the present study, we analyzed 10 sour and 9 sweet cherry cultivars for their antioxidant capacity, total polyphenolics (TPC) and total anthocyanin (TMAC) contents. In general, sour cherries showed higher levels of antioxidant capacity, TPC and TMAC. The anthocyanin contents varied from 0.16 to 6.85 and 1.41 to $127.56 \mathrm{mg} / 100 \mathrm{~g}$ for sweet and sour cherries, respectively. However, TMAC generally seems to have a limited influence on the antioxidant capacity of cherries. An amarelletype sour cherry, 'Pipacs 1' showed the highest antioxidant capacity (21.21 mmol AA/l) and TPC (44.07 mg GA/l) in contrast to its low anthocyanin content. The detected diversity presents a choice that can satisfy different consumer preferences, and meet specific nutritional requirements.
\end{abstract}

Key words: FRAP, polyphenols, anthocyanin, sweet cherry, sour cherry

\section{Introduction}

Currently a fruit grower faces severe challenges in providing high yields of good quality fruits. Quality is determined by size, colouration, flavour and other traditional attributes. However, in addition to phytosanitarian demands (fruits must be free from diseases or pests) more and more requirements are also emerging to be covered by fruits. One of these aspects gaining importance is the health-promoting power of fruits consumed either in fresh or processed. This demand also highlights the need for thorough surveys for health-related contents in fruits including commercial cultivars as well as specific landraces or locally grown genotypes. The consumption of health-promoting foods becomes more important and fashionable with many consumers willing to pay more for a healthy product.

The oxygen in the cells of the human body naturally produces free radicals. Some adverse effects (for example smoking, UV light, air pollution, inappropriate nutrition etc.) increase the intra- and intercellular quantity of active oxygen species. The free radicals may initiate a chain reaction and they are capable to deteriorate cells. Antioxidants can prevent or slow the oxidative damage. Health problems such as heart disease, inflammation, macular degeneration, diabetes, cancer etc. are all induced by oxidative damage. Antioxidants may also enhance immune defence and therefore lower the risk of cancer and infection.

Sweet and sour cherry production has long tradition in Hungary. Cultivars show great variability and it can be considered as a native species around the Black Sea and Europe. Hungarian sour cherry production ranks $8^{\text {th }}$ among all countries in terms of the production quantity. Hungary produces $4 \%$ of the total world supply (Faostat, 2007) but Hungarian cultivars are also grown in other Central European countries or even in the USA. Hungarian sweet cherry production has much restricted significance in world production compared to sour cherries. It ranks $36^{\text {th }}$ among all countries (Faostat, 2007). Most commercial cultivars are those introduced from other countries with only a limited number of Hungarian cultivars in production.

\section{Materials and methods}

\section{Plant material and sample preparation}

Ten sour cherry and 9 sweet cherry cultivars were analyzed. All cultivars and hybrids were cultivated at the same germplasm collection in the Research and Extension Centre for Fruit Growing in Újfehértó. Fruits were harvested at top maturity stage. Approximatly $100 \mathrm{~g}$ of fresh fruits were halved, seeded and homogenized and centrifuged with a Hettich Zentrifugen (Mikro $22 \mathrm{R}$; Tuttlingen, Germany) device $\left(4^{\circ} \mathrm{C}\right.$, 35 -min, $18,750 g_{\mathrm{n}}$ ); supernatants were used for redox assays.

\section{Determination of total antioxidant capacity (FRAP)}

Antioxidant capacity was determined by the FRAP (ferric reducing ability of plasma) method (Benzie \& Strain, 1996) with spectrophotometer. Ascorbic acid was used as standard. 


\section{Determination of total phenolic content (TPC)}

Total phenolic content (TPC) was measured using FolinCiocalteu's reagent according to the method of Singleton \& Rossi (1965) with spectrophotometer. The content of soluble phenols was calculated from a standard curve based on gallic acid concentration.

\section{Determination of total monomeric anthocyanins (TMAC)}

A pH differential method was applied to quantify the total monomeric anthocyanin content (TMAC) as described by Lee et al. (2008). The anthocyanin content was expressed as mg cyanidin-3-glycoside/100g fresh weight $(?=26900)$. For all spectrophotometric measurements, a spectrophotometer (Nicolet Evolution 300 BB; Thermo Electron Corporation, Cambridge, England) was used.

\section{Results and discussion}

The total antioxidant capacity of the tested sweet cherry cultivars ranged between 1.32 ('Sweet Heart') and 4.55 mmolAA L' ('Santina') (Fig. 1A). It is more than 3-fold difference between the lowest and highest values. The total antioxidant capacity of the sour cherry cultivars showed higher variations (Fig. 1B). The lowest FRAP values were measured in 'Korai pipacs' $\left(1.53 \mathrm{mmolAA} \mathrm{L}^{-1}\right)$. It is a bright red, early ripening cultivar. The highest FRAP values were determined in 'Pipacs 1', which had a FRAP value of 21.21 mmolAA $\mathrm{L}^{-1}$. It is also a bright red, amarelle-type cultivar and hence this outstanding antioxidant capacity was surprising. The antioxidant capacity of the 'Pipacs 1' was much higher compared with strawberry, raspberry, red currant cultivars and approached the range of the FRAP values of the black currant (24-33 mmolAA L ${ }^{-1}$ ) (Hegedüs et al., 2008). A 14-fold difference occurred between the FRAP values of sour cherry cultivars. The main commercial cultivars grown in Hungary ('Érdi bőtermő', 'Kántorjánosi' and 'Újfehértói fürtös') achieved lower values (3.74-4.86 mmolAA L ${ }^{-1}$ ). Two advanced selections, the ' $\mathrm{VN} 1$ ' and ' $\mathrm{VN}$ 7' had the highest antioxidant capacities after 'Pipacs 1' with 19.78 and 10.22 mmolAA L ${ }^{-1}$, respectively. These selections have black skin and flesh colours (Fig. 2).

The total phenolic content of the tested cultivars showed very similar tendencies as total antioxidant capacity. The correlation coefficient of the FRAP and TPC results was close $(r=0.805)$. It means that polyphenols define primarily the total antioxidant capacity in case of the tested cultivars. Among the sweet cherries 'Sweet Heart' showed the lowest (2.49 $\mathrm{mg} \mathrm{GA} \mathrm{ml}^{-1}$ ) and 'Santina' the highest (6.87 mg GA $\mathrm{ml}^{-1}$ ) total phenolic content (Fig. 3A). Approx. 3-fold difference occurred between the sweet cherry cultivars. Among the sour cherry cultivars the lowest TPC values were measured in 'Korai pipacs' with $2.82 \mathrm{mgGA} \mathrm{ml}^{-1}$ and the highest in 'Pipacs 1' with $44.07 \mathrm{mgGA} \mathrm{ml}^{-1}$ (Fig. 3B). It presents a more than 15 -fold variation. The main commercial cultivars showed again lower and the advanced selections showed higher values but none of the cultivars could approach the TPC of 'Pipacs 1'.

Anthocyanins are one of the most important polyphenolics in sour cherry. Anthocyanins are responsible for the bright red, blue and purple colours of fruits and are also potent antioxidants. Generally, sour cherries contained more anthocyanins than sweet cherries. In sweet cherry,
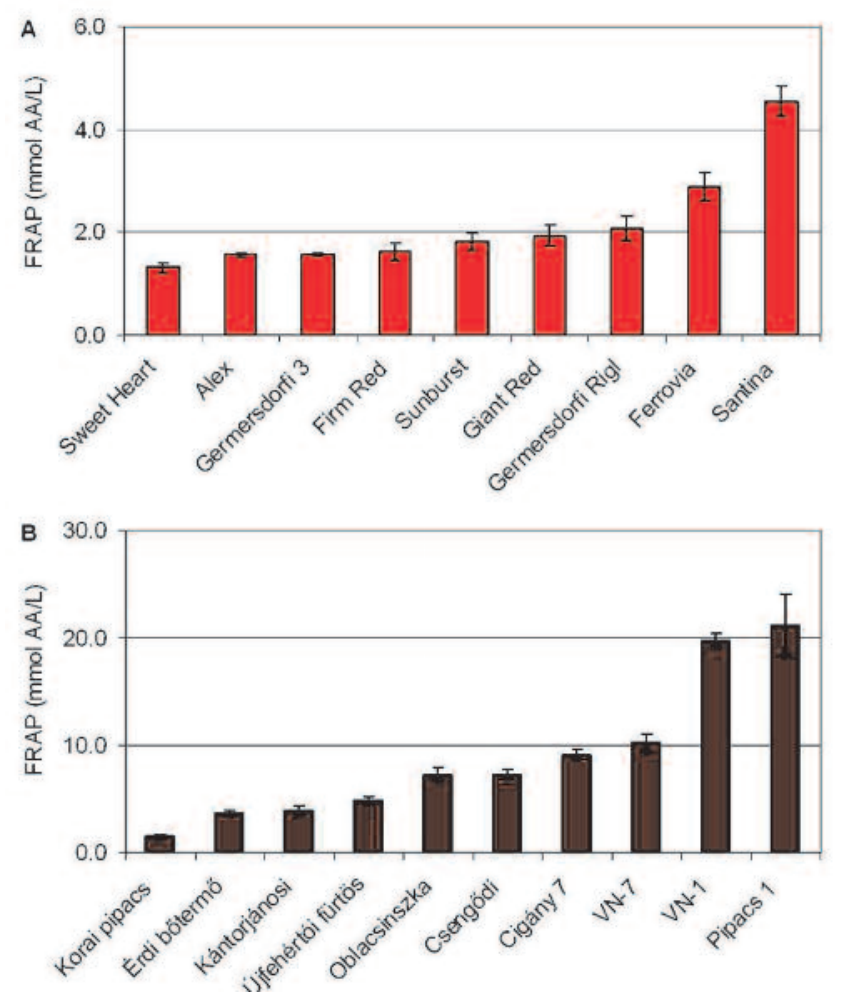

Figure 1. Total antioxidant capacity of sweet (A) and sour (B) cherry cultivars.
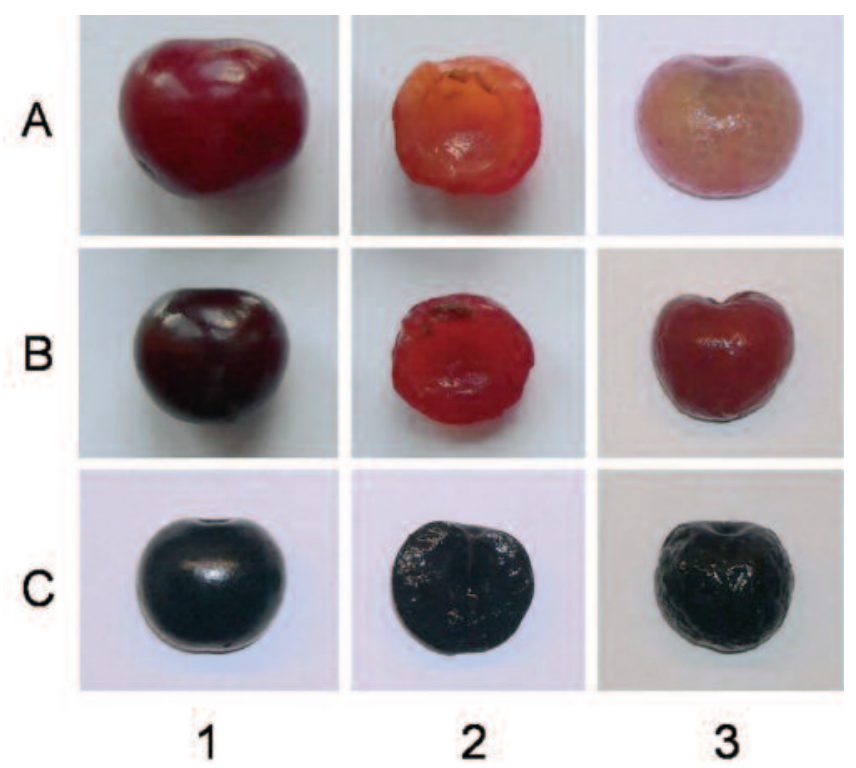

Figure 2. Visual appearance of different sour cherry types tested in the present study. A: 'Pipacs 1', B: 'Újfehértói fürtös', C: VN-01; 1: intact fruits, 2: stone cavity of halved fruits, 3 : peeled fruits. 

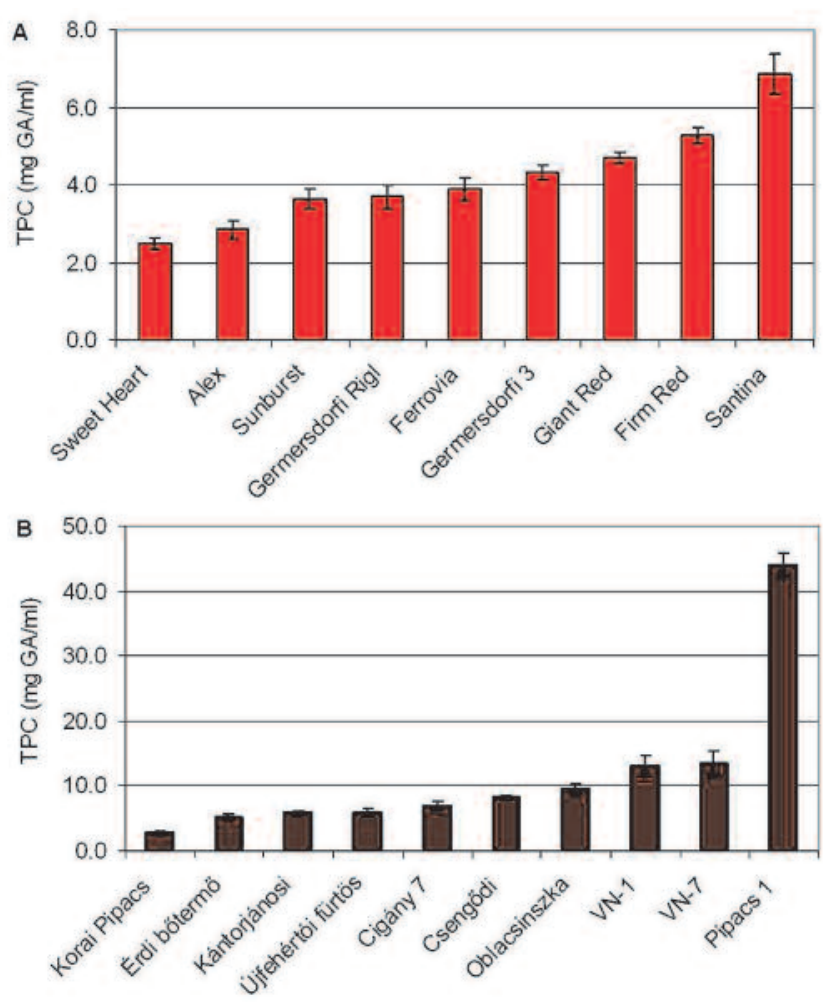

Figure 3. Total phenolic content of sweet (A) and sour (B) cherry cultivars
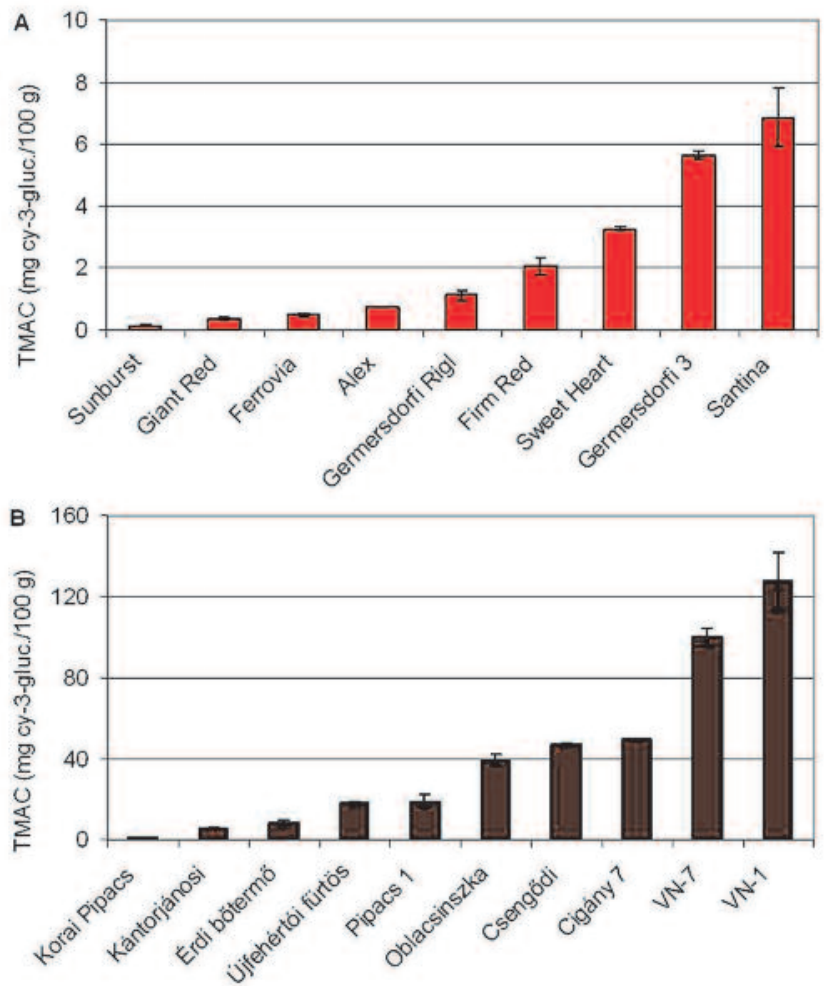

Figure 4. Total monomeric anthocyanin content of sweet (A) and sour (B) cherry cultivars

TMAC ranged from 0.16 to $6.85 \mathrm{mg}$ cyaniding-3glucoside/100 g (Fig. 4A). The lowest values were detected in the introduced cultivar, 'Sunburst' and the highest in 'Santina'. Some articles reported that berries are fruits with outstanding anthocyanin contents (Pantelidis et al., 2007). In this study the tested selections, 'VN-1' and 'VN-7' reached the total anthocyanin content of blackberries (Fig. 4B). In fruits of 'VN-1' and 'VN-7' $127.56 \mathrm{mg}$ and $100.22 \mathrm{mg}$ cyaniding-3-glucoside/100 g total anthocyanin contents were detected, respectively. The TMAC values of all tested sour cherries ranged between 1.41 and $127.56 \mathrm{mg}$ cyaniding-3glucoside/100 g.

Generally consumers suppose that dark coloured cherries may accumulate more antioxidants than light red cherries. However, our results show some important exceptions to this assumption. For example, VN selections with black skin and juice colour due to their high total anthocyanin content have lower antioxidant capacity than the yellow fleshed 'Pipacs 1' fruits with extremely low contents of anthocyanins (Fig. 2). Experiments are carried out to identify which phenolic compounds are responsible for this extreme antioxidant capacity.

\section{Concluding remarks}

In general, sour cherries were characterized by higher antioxidant capacity, total phenolic and anthocyanin contents than sweet cherries. However, both fruit species displayed great variations among cultivars. In sour cherry, some advanced selections (VN) were identified with high anthocyanin contents, while an amarelle-type cultivar 'Pipacs 1' was shown to have high antioxidant capacity presumably due to colourless polyphenolic compounds. The VN selections are characterised by good eating quality and hence are suitable for fresh consumption and processing. The fruits of 'Pipacs 1' are more suitable for processing into functional foods as fresh fruits are unpleasantly bitter or astringent.

\section{Acknowledgements}

This work was co-financed by the NKTH-OTKA K68921, OM-00042/2008 and OM-00270/2008 grants. Attila Hegedűs is grateful for receiving a János Bolyai Scholarship, HAS and the prize Excellence in science, CUB. Authors express their thanks to Ferenc Szőke for providing plant material.

\section{References}

Benzie, I.F.F. \& Strain J.J. (1996): The ferric reducing ability of plasma (FRAP) as a measure of "antioxidant power": The FRAP assay. Analytical Biochemistry, 239: 70-76.

Faostat (2007): Agriculture data. http://apps.fao.org/page/ collections? subset $=$ agriculture

Hegedüs, A., Balogh, E., Engel, R., Sipos, B.Z., Papp, J., Blazovics, A. \& Stefanovits-Banyai, E. (2008): Comparative nutrient element and antioxidant characterization of berry fruit species and cultivars grown in Hungary. HortScience 43: 1711-1715. 
Lee, J., Rennaker, C. \& Wrolstad, R.E. (2008): Correlation of two anthocyanin quantification methods: HPLC and spectrophotometric methods. Food Chemistry. 110: 782-786.

Pantelidis, G.E., Vasilakakis, M., Manganaris, G.A. \& Diamantidis, G. (2007): Antioxidant capacity, phenol, anthocyanin and ascorbic acid contents in raspberries, blackberries, red currants, gooseberries and Cornelian cherries. Food Chemistry. 102: 777-783.
Papp, N., Szilvássy, B., Abrankó, L., Szabó, T., Pfeiffer, P., Szabó, Z., Nyéki, J., Ercisli, S., Stefanovits-Bányai, É. \& Hegedüs, A. (2010): Main quality attributes and antioxidants in Hungarian sour cherries: identification of genotypes with enhanced functional properties. International Journal of Food Science \& Technology. 45: 395-402.

Singleton, V.L. \& Rossi, J.A. (1965): Colorimetry of total phenolics with phosphomolybdic-phosphotungstic acid reagents. American Journal of Enology and Viticulture. 16: 144-158. 